\title{
Detecção de Salmonella sp.em psitacídeos de cativeiro através da reação em cadeia da polimerase (PCR)*
}

\author{
MARIANGELA DA COSTA ALLGAYER \\ Cláudio Wageck Canal (Orientador - UFRGS)
}

Banca: Marisa Ribeiro de Itapema Cardoso (UFRGS), Maria Virginia Petry (UNISINOS), Sérgio José de Oliveira (ULBRA)

O interesse da Medicina Veterinária nas espécies silvestres tem aumentado gradativamente, principalmente no estudo dos contextos ecológicos de saúde. Dentro desse contexto, autores realizaram estudos com o objetivo de conhecer a importância de Salmonella sp. na saúde das aves silvestres e seu potencial de transmissão para humanos e outros animais. Informações sobre a prevalência e distribuição dos sorovares de salmonelas na população de animais silvestres e domésticos são essenciais para relacionar os possíveis reservatórios que possam ser responsáveis pela transmissão dessa zoonose. Este trabalho teve como objetivo a detecção de Salmonella sp. em psitacídeos clinicamente sadios por Reação em Cadeia pela Polimerase (PCR). Foram coletados suabes cloacais de 280 psitacídeos mantidos em cativeiro no Estado do Rio Grande do Sul, pertencentes a treze espécies, provenientes de um zoológico, um criadouro conservacionista e um criadouro comercial. O DNA das amostras foi extraído pelo método de fenol-clorofórmio e examinados pela PCR com a utilização de um par de iniciadores que amplifica um fragmento de $284 \mathrm{pb}$ do gene invA pertencente ao gênero Salmonella, resultando em 37 amostras positivas. Não houve diferença na prevalência de salmonela entre os três plantéis nem entre as 13 espécies analisadas. Não foi possível a detecção desse patógeno pela PCR com iniciadores para a identificação de $S$. Typhimurium, $S$. Enteritidis, $S$. Pullorum e $S$. Gallinarum, nem através da Técnica Microbiológica Convencional nas amostras detectadas pela PCR genérica, provavelmente devido a maior sensibilidade e especificidade da PCR genérica. De acordo com a revisão bibliográfica realizada, este foi o primeiro trabalho de detecção direta de Salmonella em psitacídeos utilizando a PCR. Os resultados indicaram que aproximadamente $13,2 \%$ dos psitacídeos mantidos em cativeiro eram portadores assintomáticos ou eram transientemente infectados pelo gênero Salmonella.

Descritores: aves silvestres, psitacídeos, Salmonella, PCR. 


\title{
Detection of Salmonella sp. in captive psittacines by polymerase chain reaction (PCR)**
}

\author{
MARIANGELA DA COSTA ALLGAYER
}

Cláudio Wageck Canal (Adviser - UFRGS)

Committee: Marisa Ribeiro de Itapema Cardoso (UFRGS), Maria Virginia Petry (UNISINOS), Sérgio José de Oliveira (ULBRA)

The interest of Veterinary Medicine on wild species has increased gradually, mainly on the field of the health ecologic contexts. In this context, some authors carried out studies in order to know the importance of the Salmonella genus on the health of wild birds and its transmission potential for humans and other animals. Information on the prevalence and distribution of the Salmonella serovars into the population of wild and domestic animals are essential for relating the possible reservoirs that can be responsible for the transmission of this zoonosis. The objective of this research was the detection of Salmonella sp. into clinically healthy psittacines by using the Polymerase Chain Reaction (PCR) assay. Cloacal swabs were collected from 280 captive psittacines in the State of Rio Grande do Sul, belonging to 13 species, coming from a zoo, a maintenance and commercial aviculture. The DNA of the samples was extracted by the phenol-chloroform method and tested by PCR using a pair of primers that amplify a fragment of $284 \mathrm{pb}$ of the invA gene from the Salmonella genus, resulting in 37 positive samples. There was no difference in the prevalence of Salmonella among the 13 species analyzed. The identification of $S$. Typhimurium, $S$. Enteritidis, $S$. Pullorum and $S$. Gallinarum was not possible by using PCR with specific primers for this serovars. The Standard Microbiological Technique (SMT) did not detect any generic PCR positive sample. Accordingly to bibliographic review, this was the first research of direct detection of Salmonella into psittacines using the PCR assay. The results showed that approximately $13.2 \%$ of the captive psittacines were asymptomatic carriers or were transiently infected by the Salmonella genus.

Key words: wild birds, psittacines, Salmonella, PCR.

** Master's Thesis no. 344 (Field: Avian Pathology). 53p. Postgraduate Program in Veterinary Sciences, Faculdade de Veterinária, Universidade Federal do Rio Grande do Sul (UFRGS), Porto Alegre/Brazil. CORRESPONDENCE: M. C. Allgayer [angelallgayer@uol.com.br]. 